\title{
Strengthening the development of the short-rotation plantations bioenergy sector: Policy insights from six European countries
}

\author{
Carlos Parra-Lopez \\ IFAPA, carlos.parra@juntadeandalucia.es \\ Martin Holley \\ CSE \\ Kevin Lindegaard \\ Crops For Energy Ltd.
}

See next page for additional authors

Follow this and additional works at: https://arrow.tudublin.ie/bescharcart

Part of the Civil and Environmental Engineering Commons, Engineering Physics Commons, and the Oil, Gas, and Energy Commons

\section{Recommended Citation}

Parra-López, Carlos \& Holley, Martin \& Lindegaard, Kevin \& Sayadi, Samir \& Esteban-López, Gonzalo \& Durán Zuazo, Víctor \& Knauer, Christoph \& Engelbrechten, Hans-Georg \& Winterber, Ralf \& Henriksson, Annika \& Lamley, Annette \& Nylander, Anders \& Paulrud, Susanne \& Leonard, Pauline \& Daly, Patrick \& Drzewaszewski, Lukasz \& Rzewuski, Wojciech. (2017). Strengthening the development of the shortrotation plantations bioenergy sector: Policy insights from six European countries. Renewable Energy. 114. 781-793. 10.1016/j.renene.2017.07.098.

This Article is brought to you for free and open access by the Dublin School of Architecture at ARROW@TU Dublin. It has been accepted for inclusion in Articles by an authorized administrator of ARROW@TU Dublin. For more information, please contact arrow.admin@tudublin.ie, aisling.coyne@tudublin.ie,gerard.connolly@tudublin.ie.

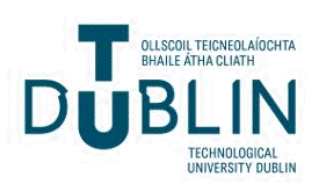




\section{Authors}

Carlos Parra-Lopez, Martin Holley, Kevin Lindegaard, Samir Sayadi, Gonzalo Esteban-Lopez, Victor DuranZuazo, Christoph Knauer, Hans-Georg von Engelbrechten, Ralf Winterber, Annika Henriksson, Annette Lamley, Anders Nylander, Susanne Paulrud, Pauline Leonard, Patrick Daly, Lukasz Drzewaszewski, and Wojciech Rzewuski 


\title{
Strengthening the development of the short-rotation plantations bioenergy sector: Policy insights from six European countries
}

\author{
Carlos Parra-López ${ }^{\text {a, * }}$, Martin Holley ${ }^{\text {b }}$, Kevin Lindegaard ${ }^{\text {c}}$, Samir Sayadi ${ }^{\text {, }}$ \\ Gonzalo Esteban-López d, Víctor H. Durán-Zuazo a , Christoph Knauer ${ }^{\text {e }}$, \\ Hans-Georg von Engelbrechten ${ }^{\mathrm{f}}$, Ralf Winterber ${ }^{\mathrm{g}}$, Annika Henriksson ${ }^{\mathrm{h}}$, \\ Annette Lamley ${ }^{\mathrm{b}}$, Anders Nylander ${ }^{\mathrm{i}}$, Susanne Paulrud ${ }^{\mathrm{j}}$, Pauline Leonard ${ }^{\mathrm{k}}$, Patrick Daly ${ }^{\mathrm{l}}$, \\ Lukasz Drzewaszewski $^{m}$, Wojciech Rzewuski ${ }^{\mathrm{n}}$
}

\footnotetext{
${ }^{a}$ Institute of Agricultural and Fisheries Research and Training (IFAPA), Centro 'Camino de Purchil', P.O. Box 2027, 18080, Granada, Spain

${ }^{\mathrm{b}}$ Centre for Sustainable Energy (CSE), 3 St Peter's Court, Bedminster Parade, Bristol, BS3 4AQ. United Kingdom

${ }^{c}$ Crops for Energy Ltd, 15 Sylvia Avenue, Knowle, Bristol, BS3 5BX, United Kingdom

d Energy Agency of Granada, Edifice CIE, 1a Planta, Avda. Andalucía s/n, 18015, Granada, Spain

e ttz Bremerhaven, Fischkai 1, 27572 Bremerhaven, Germany

${ }^{\mathrm{f}}$ Agraligna GmbH, Oststrasse 7, 38315, Schladen, Germany

${ }^{g}$ Regionale Planungsgemeinschaft Altmark, Seestrasse 2A, 39175, Biederitz, Germany

h SalixEnergi Europa AB, Herman Ehles väg 4, SE 268 31, Svalöv, Sweden

${ }^{\mathrm{i}}$ Kommunforrbundet Skåne, Gasverksgatan $3 a 222$ 29, Box 53221 00, Lund, Sweden

j SP Technical Research Institute of Sweden, Box 857, SE-501 15, Borås, Sweden

${ }^{\mathrm{k}}$ Western Development Commission, Dillon House, Ballaghaderreen, Co. Roscommon, Ireland

${ }^{1}$ Dublin Institute of Technology, Bolton St., Dublin 1, Ireland

${ }^{\mathrm{m}}$ Gmina Zaluski, Zaluski 67, 09-142 Zaluski, Poland

${ }^{\mathrm{n}}$ Mazovian Agricultural Advisory Centre, Ul. Czereśniowa 98, 02-456, Warszawa, Poland
}

\section{A R T I C L E I N F O}

\section{Article history:}

Received 7 March 2017

Accepted 24 July 2017

Available online 24 July 2017

\section{Keywords:}

Short-rotation plantations - SRP

Short-rotation coppice - SRC

Woody biomass

Bioenergy

Bioeconomy

Policy design

\begin{abstract}
A B S T R A C T
This paper, based on a participatory methodological framework involving expert stakeholders and researchers from six European countries (Germany, Ireland, Poland, Spain, Sweden and UK), analyses the priority issues for the development of short-rotation plantations (SRP), and proposes a series of policy strategies to strengthen this development. The results indicate that there is a lack of awareness of the multifaceted benefits of SRP at the level of farmers, policy makers and public authorities. More research is required to put a value on the multifunctionality of SRP and justify its public support. Small-scale projects using established technologies are also required with energy crops introduced in a phased manner. The simultaneous dissemination of this knowledge upwards to policy makers and downwards to producers and farmers is critical in the success of SRP. Also, greater financial support on both the supply and demand side is highlighted as being necessary: on the supply side linking multifunctional benefits of SRP and targeted payments, along with increased long-term contractual arrangements between farmers and energy plant operators; demand side incentives should overcome any difference in price between fossil fuels and energy crops. Groups to lobby for the uptake and support of SRP and bioenergy are also of necessary.
\end{abstract}

() 2017 Elsevier Ltd. All rights reserved.

\section{Introduction}

Renewable energy is at the core of EU's long-term energy

\footnotetext{
* Corresponding author.

E-mail address: carlos.parra@juntadeandalucia.es (C. Parra-López).
}

strategy because it helps to reduce greenhouse gas emissions, diminishes the need for energy imports making Europe more independent, and provides EU countries and their regions with new 'green' jobs and high value-added exports [1]. The European Directive 2009/28/EC on the promotion of the use of energy from renewable energy sources (RES) [2], which is part of the Climate and Energy Package, established a 20\% target for the share of 
energy from renewable sources in gross final consumption of energy by 2020 for the EU. This Directive specifies national renewable energy targets for each country, taking into account its starting point and overall potential for renewables. In order to achieve this, a possible strategy suggested by the Commission was to triple the use of biomass energy compared with 1997 [3]. Biomass is expected to contribute to about half of the EU Renewable Energy target in 2020 and bioenergy is expected to remain the main RES contributor [4]. For this reason, biomass has become a flourishing sector that requires innovative solutions to meet the EU and international demand. It is necessary to ensure that the expected increases in biomass use takes place within a sustainable framework and biomass sustainability is thus a key issue $[4,5]$.

Short-rotation plantations (SRP) are plantations of fast growing trees that are harvested in periods from 2 to 20 years and managed as coppice (short rotation coppice - SRC) or as single stemmed trees (short rotation forestry - SRF) The woody biomass produced can be used in applications such as large scale district heating (in combined heat and power -CHP- plants), small-scale boilers (when processed into more refined forms of wood fuel), and electric power generating stations (in dedicated bioenergy plants or in combination with other fuels such as co-firing with coal). SRP are considered a source of low-carbon fuel, as most greenhouse gas (GHG) emissions released during combustion will be re-absorbed by new growth, and can make a positive contribution to climate change targets [6-13]. Energy generation from SRP is very energetically efficient [7], with an output/input ratio greater than 18 in poplar [14]. SRP can also bring a wide range of other environmental benefits related to biodiversity, soil eutrophication/acidification and quality, reduced soil erosion, air and water quality, land remediation, and flood defence, among others [8,15-19] as long as they are not cultivated in areas of high nature-conservation value [20]. SRP may contribute to locally sourced energy systems which reduces dependency on fossil fuels and improves energy security [16]. The land intensity use of SRP is greater than other renewable energy sources, but it is a stock resource whereas wind and photovoltaics are intermittent [16]. Biomass generation from woody energy crops takes on special importance in farmland with lowproductive capacity or deforested and unproductive forest areas with consequent beneficial effects on the environment, and may represent a new economic niche in marginal rural areas [16,21-24]. Integration of biomass crops into agricultural landscapes could stimulate the rural economy, thus counteracting negative impacts of farm abandonment or supporting restoration of degraded land [20].

Despite its potential benefits and demand for bioenergy expected to increase significantly, the development of the SRP sector in the EU has been low and very uneven in the different European countries. Sweden, the leading country, is considered as an example of a relatively successful development and use of woody plantations for bioenergy [25]. Production, pre-treatment and use of SRP was fully developed in Sweden twenty years ago [26]. Subsidy and tax incentives for energy crop production, an increased $\mathrm{CO}_{2}$ tax on fossil fuel, an already existing biofuel market in the country and ready markets in district heating plants are among the main drivers for plantation of willow during the period 1986-1996 [27-29]. The total acreage of willow reached a peak at about 18,000 ha but has decreased to about 10,000 ha and it is still decreasing due to mismatch between the location of plantations and the market, slow development of the harvest technology and, lately, the competition from imports of cheap waste biomass. The relatively low biomass yields of willow may also be a reason due to a lack of management activities during the early stages of cultivation, the choice of inferior land for plantations, and the level of personal involvement of farmers [30]. In other European countries the share of SRP is lower due to diverse factors. For instance, in Germany the total area of SRP has increased to about 6000 ha in the last decade. In this case the crop of choice is poplar grown over longer rotation cycles on marginal lands with sufficient water supply [22]. In the UK, despite some progress being made in the late 1990's and early 2000s there has been little net growth in the area planted in recent years [31]. In this country, obstacles hindering progress have been identified, including the lack of long-term supportive energy crops policy, the lack of competitiveness of long-term perennial crop options compared to annual crops, and large-scale support schemes tending to favour imported biomass rather than supporting domestic supply [15]. In other countries of the South and East of Europe, the development of the SRP sector is even more nascent. In Spain, for instance, the area devoted to SRP is restricted to experimental plots, which have demonstrated a high potential for biomass production [32]. Critical factors conditioning the spreading of the SRP sector in Spain include lack of information on operating and selling costs and uncertainty of return on investment from long-term plantations; lack of tools to support the production, processing, and use of biomass; and limited supply of woody biomass from SRP and market availability [6,33,34]. Perennial energy crop development is just starting in Poland, with SRP and perennial grasses covering 8700 ha [35]. The main obstacles to the development of SRP are the competitiveness of energy crops compared to grain production [35] and the plentiful reserves of fossil fuel energy sources, especially coal.

Public policies promoting and supporting the development of the SRP bioenergy sector seem to have failed and a lack of coherent policy design at EU level is patent. In this sense, public policies are defined and implemented at national and regional level, but should be further coordinated and planned at EU level. This is because decisions taken by one country inevitably have an impact on other EU countries [36]. The optimum energy mix, including the swift development of renewables, needs a continental market at least; fragmented markets not only undermine security of supply, they also limit the benefits which energy market competition can bring [36]. Lindegaard, Adams, Holley, Lamley, Henriksson, Larsson, von Engelbrechten, Esteban Lopez and Pisarek [37] reviews the history and state of SRP at EU level and highlights some policy recommendations for the development of SRP. However, a more finetuned bottom-up approach arising from a deeper analysis of the particularities at country/region level is lacking.

The current research is carried out with such a bottom-up perspective within the EU's Framework 7th programme Rokwood project. ${ }^{1}$ This project attempted to increase the market penetration of woodfuel produced from SRP. The project involved a large consortium of partners from six European countries, representative of the uneven development of SRP: Germany, Ireland, Poland, Spain, Sweden and UK. Within each country, a case study region is analysed (Table 1). Each region is represented by a cluster of three partners comprising the R\&D\&I triple-helix concept: business entity, research entity and local/regional authority. Some of the regions are well developed in terms of SRP planting and infrastructure (e.g. Skåne in Sweden) whilst others are in their infancy (e.g. Midlands \& Western in Ireland).

In this context, the aim of this paper is to provide insights on supportive policy measures to strengthen the development of the SRP bioenergy sector in the EU by developing a series of strategies

\footnotetext{
${ }^{1}$ Project "European Regions fostering Innovation for Sustainable Production and Efficient Use of Woody Biomass (ROKWOOD)". European Commission - Seventh Framework Programme Coordination and Support Action. European Union FP7Regions-2012-2013-1 (Transnational Cooperation between Regional ResearchDriven Clusters), Grant Agreement No. 319,956. www.rokwood.eu.
} 
Table 1

Characterisation of the cluster regions of the six countries.

\begin{tabular}{|c|c|c|c|c|c|c|}
\hline & Northern (Germany) & $\begin{array}{l}\text { Midlands \& } \\
\text { Western } \\
\text { (Ireland) }\end{array}$ & Mazovia (Poland) & $\begin{array}{l}\text { Andalusia } \\
\text { (Spain) }\end{array}$ & Skåne (Sweden) & South West (UK) \\
\hline Population (millions) & 19.5 & 1.1 & 5.3 & 8.4 & 1.3 & 5.3 \\
\hline Area (m ha) & 13.77 & 3.25 & 3.56 & 8.76 & 1.09 & 2.38 \\
\hline Area of SRP today (ha) & 3600 & 117 & 1100 & $150-170$ & 2042 & 93 \\
\hline Forest cover (ha) & 2.37 & 0.34 & 0.85 & 2.54 & 0.39 & 0.25 \\
\hline$\%$ of land cover that is forest & 17.2 & 10.5 & 23.8 & 29.0 & 35.7 & 10.5 \\
\hline $\begin{array}{l}\text { Installed capacity of biomass } \\
\text { (MWth) }\end{array}$ & approx. 500 & 94 & 2480 & 1555 & 1840 & 280.3 \\
\hline $\begin{array}{l}\text { Number of biomass heating \& } \\
\text { CHP installations }\end{array}$ & 7500 & 951 & 32,262 & $\begin{array}{l}23,431 \text { heating } \\
\text { and } 18 \text { power } \\
\text { plants }\end{array}$ & $\begin{array}{l}33,140 \text { heating and } 33 \\
\text { district heating and } \mathrm{CHP} \\
\text { plants }\end{array}$ & 3414 \\
\hline Area of agricultural land (ha) & 6.91 & 2.05 & 2.31 & 3.85 & 0.51 & 1.91 \\
\hline $\begin{array}{l}\% \text { of land cover that is } \\
\text { agricultural }\end{array}$ & 50.2 & 63.1 & 65.0 & 43.9 & 46.3 & 80.4 \\
\hline $\begin{array}{l}\text { Predominant agricultural land } \\
\text { use }\end{array}$ & $\begin{array}{l}\text { Cereal farming and } \\
\text { cultivated pasture }\end{array}$ & $\begin{array}{l}\text { Pasture/ } \\
\text { grassland for } \\
\text { livestock }\end{array}$ & $\begin{array}{l}\text { Fruits, vegetables, } \\
\text { potatoes, cereals, } \\
\text { canola, berries }\end{array}$ & Olive plantations & $\begin{array}{l}\text { Livestock farming and } \\
\text { arable crops cultivation }\end{array}$ & $\begin{array}{l}\text { Livestock } \\
\text { farmingparticularly } \\
\text { dairy cows and sheep }\end{array}$ \\
\hline
\end{tabular}

for policy makers, public authorities and governmental agencies, anchored in an analysis at country/region level. These strategies are intended to guide the development and execution of National and Regional Action Plans and EU regulations for the SRP bioenergy sector.

\section{Material and methods}

Four methodological phases were followed to (1) identify priority issues to be addressed and potential solutions for SRP development, (2) select policy options, (3) define and (4) validate the policy strategies for the development of the European SRP bioenergy sector. The methodological framework followed, summarising the analyses carried out and the data sources used in each phase, is shown in Fig. 1.

\subsection{Identifying priority issues and potential solutions}

The aim of the first phase was to define priority issues to be addressed and potential solutions for the development of the SRP bioenergy sector based on robust evidence on opportunities for and constraints against SRP in the six analysed EU countries. For this, each cluster performed an in-depth PESTLE (Political, Economic, Social, Technological, Legal and Environmental factors) analysis (see e.g. Kolios and Read [38]) for their respective region. The objective was to identify factors currently affecting the production and use of SRP, and those which are likely to affect it in the future. The partners were encouraged to consult with expert stakeholders outside the cluster group, and in most cases a structured workshop was arranged to ensure that a wide range of views was captured. As an example, the results of the PESTLE analysis for the case of Andalusia, Spain are summarised by Sayadi, Parra-López, Durán-Zuazo and Magnolfi [33] and Parra-López, Sayadi and Durán Zuazo [6].

Subsequently, the PESTLE outputs were condensed into a more manageable form by the completion of a SWOT (Strengths, Weaknesses, Opportunities, Threats) analysis (see e.g. Srdjevic, Bajcetic and Srdjevic [39]). Each cluster populated a SWOT chart made up of four quadrants to identify internal strengths and weaknesses within the SRP bioenergy sector alongside external opportunities and threats. The SWOT analysis was heavily used both to identify important issues to be addressed and to find potential solutions, with most of the solutions being derived from weaknesses and threats. Solutions were sought by looking for relationships: for example, a strength that could overcome a threat or an opportunity that could negate a weakness. Although there may not always be direct relationships between internal strengths/weaknesses and external opportunities/threats, some may become apparent when comparisons are made. An example from the UK cluster is shown in Fig. 2.

\subsection{Selecting policy options}

There was a range of issues identified, most of which could be addressed by solutions that range in terms of impact and effectiveness (and they also differ in the level of policy making to which they are targeted). The potential solutions that are most likely to address the critical issues and be encouraged and adopted by their translation into policy relevant to each region (and most likely each country) were taken forward as policy options.

In determining the policy options some external factors were also considered, including: 1) What policies are already in development that might impact the SRP bioenergy sector?; 2) If we are to successfully steer the policy framework are there any deadlines that need to be met?; 3) Are there any key consultations that should be responded to?; 4) What is the potential for support for SRP under the next round of the Rural Development Programme?; and 5) Are there any prospects of other public funding for SRP?

Depending on the 'level' and specific detail of policy options being proposed, the options were tested against SMART characteristics i.e. where possible, each should be specific, measurable, attainable, relevant and time-bound. In the event of there being several policy options that addressed the same issue, an attempt was made to combine possible solutions into one coherent set of policy options.

\subsection{Defining policy strategies}

Once the policy options were narrowed down and decided upon, each regional cluster chose a number of them to elaborate on more fully in the final policy strategies. Policy strategies must provide detail and justification, and indicate to whom the policy is targeted (e.g. local, regional, national policy makers) and which government body would be responsible for its implementation. Each of these strategies explicitly answered the following questions: 1) What is the issue?; 2) How could this be tackled?; 3) What are the benefits?; and 4) Who should take this forward? To support and illustrate the proposed policy strategies, best practice case studies identified previously in the project were used [40]. 


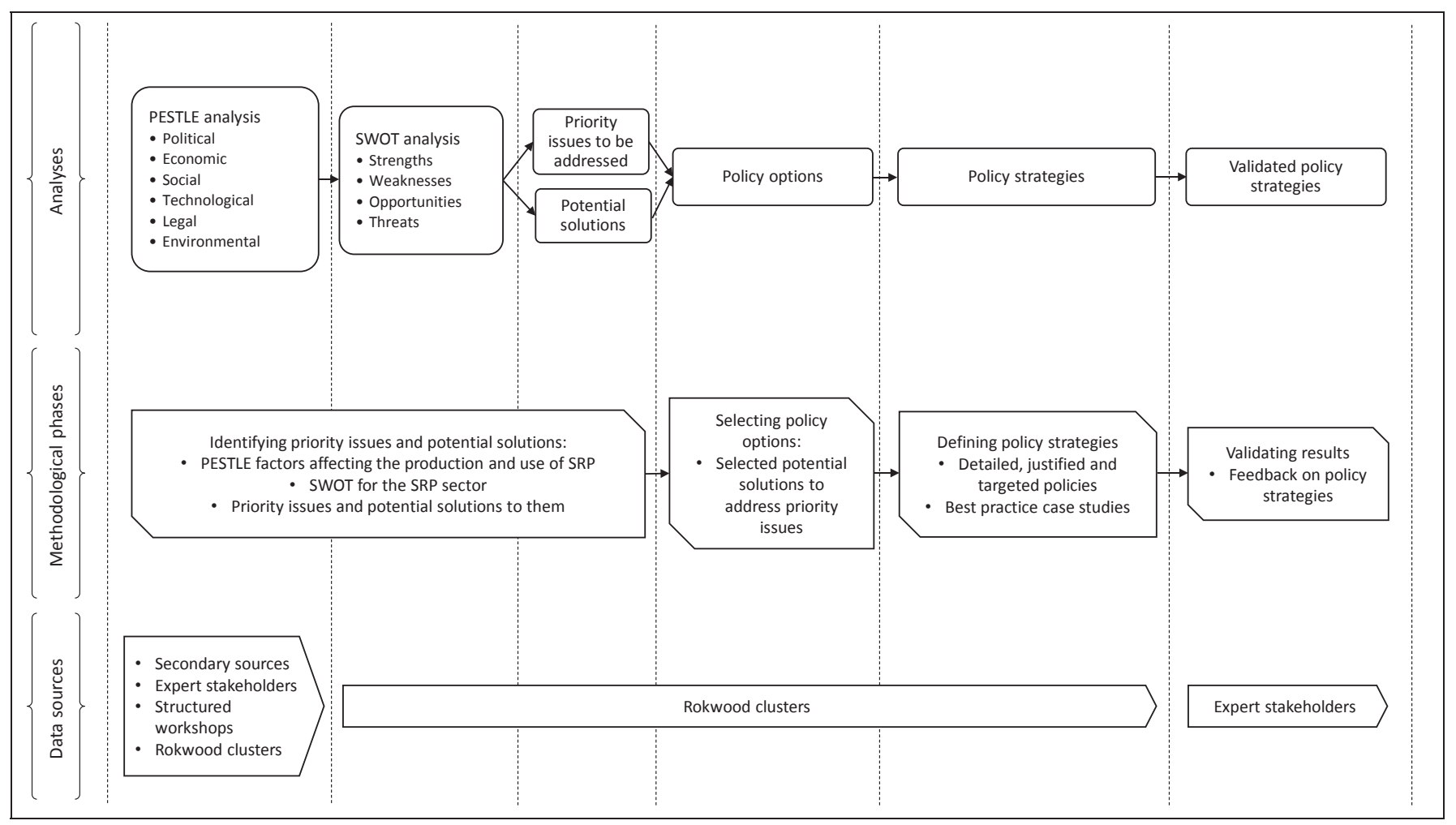

Fig. 1. Methodological framework.

\subsection{Validating results}

In order to ensure that the final policy strategies were suitablytargeted and that they thoroughly addressed the key issues identified, each of the clusters distributed draft copies of their strategies by email to relevant stakeholders for comment and validation. These stakeholders included policy-makers at local, regional and national levels, academics specialising in related subjects (primarily agricultural, economic development or energy-based), and bioenergy consultants. Where it was considered appropriate, these initial mail-outs were quickly followed up with a further email or phone call with the aim of garnering letters of support from across the sector. Each cluster recorded a list of all individuals or organisations involved in the consultation process.

\section{Priority issues}

\subsection{Germany (northern)}

\subsubsection{Highlight the positive ecological effects of SRP}

Within the framework of Germany's energy policy, which focuses on the integration of renewable energy resources, SRP can make a very positive impact on the climate. Since SRP is carbon neutral, national energy targets can be achieved and the path to energy security facilitated. The energy efficiency ratio of input and output for SRP can be regarded as favourable. Since SRP requires few machinery movements during the cultivation period, it encourages living organisms in the ground. Birds too settle in SRP thanks to favourable living conditions. The fauna found in SRP is highly diversified in contrast to arable fields. Willow and poplar provides a habitat for many small animals.

In addition, SRP can contribute to a constant groundwater level. Crops such as poplar or willow are deep-rooted in contrast to regular field crops, which is why they can serve as water repositories for relatively dry soils. This also contributes to a loosening of the upper soil. SRP enhances water quality by absorbing nutrients such as nitrates. The roots contribute to improving the structure of the upper soil and therefore reduce the risk of ground erosion. These ecological benefits from SRP as well as its energetic efficiency make it more attractive than maize cultivation. In areas with a high density of grassland, the planting of SRP is not permitted for reasons of nature conservation and greening. This hinders the implementation of SRP.

\subsubsection{Inclusion of farmers and local authorities}

At earlier stages of biomass production from SRP, the status of the land used remained unclear. Whether farmland with SRP remained farmland or became woodland after a certain period of cultivation was uncertain. The EU created a regulation to clarify the status of SRP on farmland [41], which enables farmers to obtain subsidies for SRP. The EU regulation states that land on which SRP is planted is not categorized as woodland but as field crop. However, German farmers are still very sceptical towards SRP and need support and information.

They often struggle when it comes to very long cultivation periods which they cannot complete as tenancy contracts of at least 20 years are not awarded. Furthermore, farmers often regard the switch from common field crops to SRP as too complex. This is due to completely different cultivation methods in the areas of growing, harvesting and tilling. SRP can, however, be used for different types of land and natural conditions, such as wet or dry ground and areas which typically are uneconomic to cultivate with food crops. It is of utmost importance that a plant variety suitable for SRP is selected. The first SRP farmers have sometimes planted untested or poorly adapted varieties on their fields. This has led to bad harvest results.

Besides farmers, various district councils and municipalities in Germany own fallow land. Such local authorities often lack the knowledge and funds to implement any activity on unused land. 

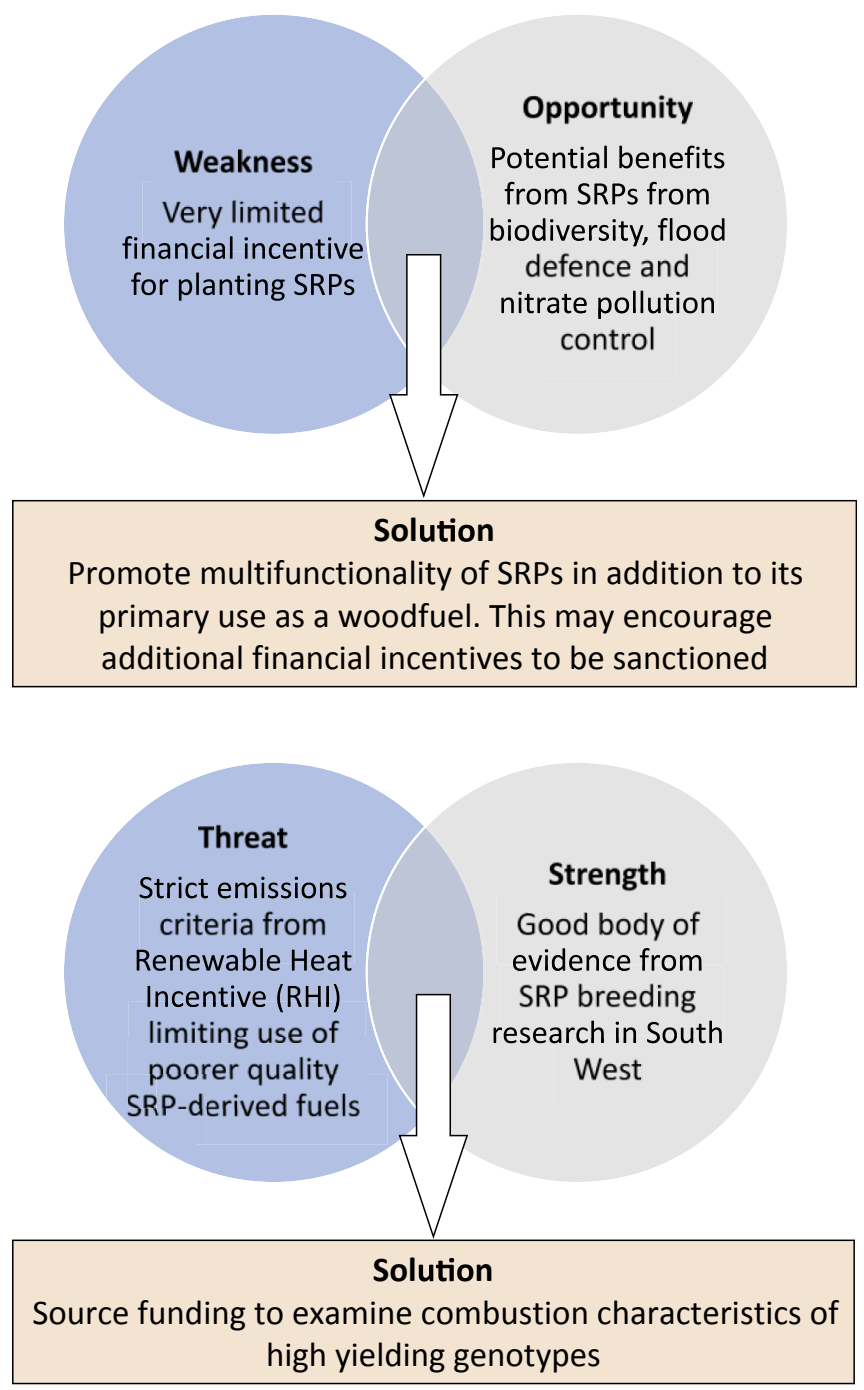

Fig. 2. Examples of using SWOT outputs for developing potential solutions in UK.

SRP can play a role here in bringing these sites back into use.

\subsubsection{Enable regional value creation and create value-added chains}

Some regions in Germany lack favourable economic structures, e.g. in the northern part of Saxony-Anhalt. There is a high level of unemployment, low population density, and the age demographic shows that the average age of the local population is rising as a result of increased life expectancy and migration of young people. This is why such areas are suffering severe economic problems. Energy-driven economic sectors such as bioenergy can create critical value for these regions. Since it is already a strong market in the region of Altmark, in the north of Saxony-Anhalt, biomass from SRP could play an important part in the region's energy mix. Furthermore, sufficient farmland and other redundant land is available which can be used for SRP production. The production of SRP wood in such regions can create welcome value chains. Producers, processing industries, distributors and customers could be located in one region and generate overall value for the German economy.

\subsection{Ireland (midlands \& western)}

\subsubsection{Development of a policy development group}

Compared to other existing conventional players in the energy market (oil, gas, electricity and wind), the lobby groups for bioenergy and SRP in particular is small in scale. The other players in the energy market are commercial entities with access to funding and fund raising capacity to support their industry. This has also been identified by the Irish Bioenergy Association (IrBEA), a selfgoverning association of voluntary members which aims to promote the bioenergy industry and to develop this sector on Ireland. In 2014 IrBEA established an Energy Crops group to engage with policy makers and influencers [42]. The aim of this group is to promote, support and develop the energy crops industry across the island of Ireland, representing both the growers and businesses involved'. The group has participants from state organisations (Teagasc, Western Development Commission), growers, processors and end users (Bord na Mona and Biotricity).

Additionally, there is also a personnel deficit in government and state agencies, with a loss of bioenergy expertise in policy making. Policy makers are more familiar with wind generation for electricity, and forget the need for heat energy to meet RES (renewable energy sources) targets. There is a need for the development of a group to lobby for the benefits of SRP in meeting these targets, as an alternative to traditional forestry.

\subsubsection{Education and information for the sector}

In Ireland there is a dominance of traditional forms of agriculture, which is dominated by livestock and cereal farming and the main competition for land use comes from dairy, beef or arable on good quality land. On poor quality land, energy crops are unable to complete with forestry due to the superior financial support in that sector. Another issue is the conservative nature of the farming sector in which there is the perception that SRP is not true farming, but carried out by inactive farmers who aren't interested in the traditional crops or methods.

Therefore, the bioenergy sector and SRP are seen as complex. This stems from a lack of understanding and education of the farming sector. In the past, bad experiences and news stories, particularly the failures relating to the miscanthus crop, and poor yields on some willow crops, have damaged the entire SRP industry. With this, there is a need to educate farmers about the bioenergy industry and to help demystify the myths around SRP. Additionally, it is difficult for energy crops to compete financially with established farming practices.

\subsubsection{Re-classification of energy crops and address the disparity with forestry supports}

The main support for the establishment of SRP in Ireland is the Bioenergy Scheme (2007 - present), administered by the Department of Agriculture, Food and the Marine [43]. In this, farmers could apply for establishment grants of up to $€ 1300$ per hectare to cover $50 \%$ of the costs of establishing SRP willow or miscanthus. This level of support is not considered adequate compared to the establishment costs and the high cost of planting material. Under this scheme (2007-2014), 2467 ha of miscanthus and 1046 ha of willow was planted. One of the conditions of this scheme was that a minimum of 3 ha and a maximum of 30 ha could be planted.

In comparison to this, a number of schemes support the establishment of forestry. The Afforestation Grant and Premium Scheme, the Forest Environment Protection Scheme (FEPS) and the Native Woodland (Establishment) Scheme are available from the Forest Service of the Department of Agriculture, Food and the Marine. The grants available in these schemes generally cover all of the costs associated with the establishment and early management of a forest. The rate of afforestation grant and annual forest premium available under these schemes depends on the quality of the land and the type of tree species it can grow. Annual forest premiums are available to compensate farmers and non-farmers for the loss in 
income earning potential from the afforestation of their land. New entrants (2013) are entitled to forestry premiums ranging from $€ 126 /$ ha to $€ 515 /$ ha dependent on tree species, soil type and farmer status. This premium is payable for a period of up to 20 years in the case of farmers or 15 years for non-farmers.

When comparing the initial establishment support for forestry and SRP in Ireland, it is clear that investing and developing forestry is a financially more attractive option for farmers. This disparity continues for the lifetime of the crop and also affects how the crop is dealt with under taxation law (income tax, Capital Gains Tax).

\subsubsection{Development of a renewable heat initiative to achieve RES-H targets}

In Ireland, there is a need to identify the likely economic impact of the missing of the 12\% RES-H targets for 2016 and develop counter measures to aid the closing of the gaps and develop support mechanisms that will allow for the targets to be achieved by utilising minimal support mechanisms. It has been estimated that the financial implications of missing the target would be between $€ 100 \mathrm{~m}$ and $€ 150 \mathrm{~m}$ per year [44].

It is also difficult for renewable heat companies to compete with existing fossil fuel heat generation, and to seek financing for their technologies. The addition of an incentive would make this industry more attractive on a financial level, and would be a benefit to companies when organising finance for their operations.

\subsection{Poland (mazovia)}

\subsubsection{General lobbying activities, especially in the political and} business sectors

At the present time, in Polish legislation at national and regional level there is little mention of biomass usage for energy and heat production. The entire energy production process in Poland centres on coal as an energy source. Therefore, when considering any kind of legislation regarding energy and heat production, it is hard to compete with a large, already existing sector with a proper, highly developed infrastructure and trade net which starts with coal mining and ends with coal-burning stoves located in almost every household in the country. This structure has its lobbying power, which is deeply ingrained in policy makers' awareness and therefore influences all laws enacted up to the highest political level.

The lack of proper legislative mechanisms has its consequences in the financial aspect of this issue. Currently, it is much cheaper to produce any kind of energy from coal than from biomass. Even when using the highest quality coal, $8500 \mathrm{kWh}$ of energy can be obtained from a tonne of material costing no more than 900 zlotys $(202 €)$. To produce the same amount of energy from wood pellets, 1.6 tonnes of material at a cost of 1520 zlotys ( $342 €$ ) would be necessary. The economic advantage of using coal is therefore obvious.

\subsubsection{Support for biomass providers and development of a proper market}

Consumers of biomass for heating purposes in Poland can be divided currently into individual and public consumers. Individual consumers are owners of households which use stoves adapted to burn biomass such as oats or all kinds of woody fuel (briquettes, pellets and chips). This is a very small group, mainly farmers who obtain their fuel from their own crops or their own forests. Public consumers are mainly public heating facilities which are monopolies in biomass consumption in the market. They use some woodchips from willow for heating purposes but there are only a few growers due to technological obstacles and poor financial support.

\subsubsection{Knowledge dissemination and technical and technological development}

For any involvement in a new activity, a certain knowledge base is required. The same applies to suitable tools and machinery, since not all tasks can be performed by hand alone. Special machinery is required to produce woody biomass. Unfortunately, the availability of biomass production and processing devices or machines is rather poor in Poland.

There is neither direct access to this kind of machinery nor are there dealers selling the machines. It would be a considerable risk for these dealers to enlarge their range of biomass-processing machinery due to the low number of orders in Poland. Some years ago, there was a short boom for woodchip and pellet production and use for heat generation. During this boom, a number of companies were founded which built machinery for the production and use of woody biomass, mainly by private customers. However, this increase was short lived and slowed down significantly after a while. Those few farmers who are engaged in biomass production in Poland, and in the region of Mazovia, use machinery intended for lumber facilities (mobile wood shredders for branches), farming (corn choppers) or equipment they have built themselves and based on their own ideas. These are often characterized by poor quality and/or poor efficiency.

\subsection{Spain (Andalusia)}

\subsubsection{Promote resources to share information on SRP among all stakeholders}

In Spain, two of the main problems hindering market development are the abundance of other sources of waste biomass and the lack of information about SRP. With no information on this market available, it is difficult for policy makers, farmers and enterprises to establish the right parameters and undertake the right action to foster market implementation. To date, the main developments in the field of SRP in Spain have been related to electricity power plants due to subsidies, with limited information for the general public. As a result, there are only a few specialized market players. However, the Spanish regulation 'Real Decreto-Ley 1/2012' derogated subsidies to electricity power plants [45] due to electricity supply surplus [46]. The Spanish business model must therefore change totally in order to adapt to this situation. This needs to shape the views of and/or inform policy makers, research institutions, farmers, industry and citizens about the possibilities of SRP and its advantages, of which only a few players in the country are currently aware.

\subsubsection{Promotion of biomass and focus on its local production}

Biomass used properly can bring many recognized benefits and policies which already promote the sector should be maintained and/or strengthened. Nevertheless, bad practices related to the biomass market are unfortunately well-known, such as deforestation, food competition, indirect land use change, etc. As a consequence, and due to the specific situation in Spain, i.e. the fact that the electricity grid will not accept any more input in the next few years, there is a need to adapt policies for the promotion of biomass to the new situation, with a focus on heat demand and biofuels produced as locally as possible.

All policies have the dual objectives of using waste biomass to solve waste problems at the same time as producing energy. This is a sensible approach. However, if the aim is to find alternatives to fossil fuels and become less dependent, far more biomass will be needed from within Europe and not large volumes imported from outside. SRP could help facilitate the local supply of biomass into the energy system and enable less dependence on imports, but work in this direction needs to commence immediately. 


\subsubsection{Develop specific legislation adapted to SRP characteristics}

In the CAP, the 'greening focus' of legislation states that each farmer with over 15 ha of land must use $5 \%$ of his arable land for ecological purposes [47]. This is encouraging for the SRP market, but the Member States are obliged to transpose EU parameters into their individual national parameters. It is therefore essential that the specific parameters in Spain be assessed in order to let the market grow. Such parameters include cultivation methods, species, fertilization, multi-functionality of SRP, etc.

There are other issues in national legislation which must be solved, such as consideration of agricultural land or forest land depending on the species planted. This means that land classification can change if trees are planted on farming land in order to produce energy in short rotation periods. Clear legislation must be developed here.

\subsubsection{Promote policies and resources to develop better $R \& D$}

Water is limited in southern Spain and SRP needs water. If this aspect is not addressed, the market will not increase further in this country. There is therefore a need for policies/support schemes/ technologies to develop species adapted to the Spanish climatic conditions, that use water more efficiently, utilize wastewater or use water on specific land areas where its effects are beneficial to the soil.

Moreover, competition in terms of costs is also related to logistics, energetic yields, downscaling systems, biofuel transformation and improvement of the production process in general. Improvements are therefore not only needed in the area of irrigation but in all these areas too in order to make SRP competitive.

\subsection{Sweden (Skåne)}

\subsubsection{Willow as part of the greening in the CAP}

Stronger support for SRP through the CAP is required in order to bring the SRP sector forward and help Sweden and the EU reach their renewable energy targets. As mentioned previously, the CAP 2014-2020 demands that all farms with more than 15 ha of land must declare $5 \%$ of the total area as Ecological Focus Areas (EFAs) in order to obtain full financial support from the EU [47]. These EFAs must be close to nature, being extensively cultivated or not cultivated at all. SRP is one of the potential crops which could be grown in the EFAs. However, there are restrictions which prevent the economic operation of SRP on EFAs such as the restrictions on chemical inputs in the establishment year of the crop. In addition, the weighting factor, which is used to calculate the total EFA on the basis of the ecological value of the crop, is the lowest of all crops (0.3) [48], and means that a much greater area of land needs to be committed compared to other options.

\subsubsection{Willow as a multifunctional crop}

The multi-functional benefits of willow and other SRP are not recognized and therefore not remunerated. Many of these multifunctional benefits and impacts on the ecosystem are not well known and there are only a few examples in practice. As a result, many of these potential applications are missed by policy makers and organisations responsible for implementing support schemes. Growing willow for multi-functional purposes will provide society with a large number of socio-economic and environmental benefits whilst ensuring maximum land use and resource efficiency. The benefits of such willow applications include: tackling climate change and promoting local energy security; increasing farm biodiversity; improvements in water quality; a possible flood defence method; carbon sequestration; rebuilding bee and other pollinator populations; rehabilitation of contaminated land; and rapid-growing shelterbelts and windbreaks. Many of these benefits are hard to quantify and to date there has been little research carried out on the potential economic value to society of SRP multifunctionality (see the Introduction section for references).

\subsection{UK (South West)}

\subsubsection{Evidence base review of SRP costs and benefits}

SRP is more than an energy crop; it is a multi-functional crop with a range of environmental benefits, as already stated. It has a unique set of attributes based on its ability to be easily propagated, its fast growth and low level of inputs. SRP has the potential to: (1) help boost the economy through job creation, local retention of revenue and diversification of income for farmers and landowners; (2) help solve socio-economic issues such as reducing fuel poverty through low-cost local woodfuel supply; (3) achieve local and national energy and environmental goals such as increasing security of supply and reducing carbon emissions; and (4) provide a whole host of practical applications and ecosystem services such as flood defence, water quality improvement and increases in populations of beneficial insects.

Other crop options can deliver some of these benefits, but only SRP willow can provide a full package and provide these benefits rapidly. Although there is already a significant body of evidence to support these claims, as previously mentioned in section1, it needs to be consolidated and further research deed to be undertaken to value the benefits as a whole. Unfortunately, the breadth of potential across different areas means that use of SRP straddles Government departmental remits and typically falls between two stools, with the result that incentives for SRP production are not being implemented and opportunities not realised.

\subsubsection{Enabling SRP infrastructure to supply local heat markets}

In many UK regions local infrastructure does not exist to harvest, store and process biomass produced from energy crop plantations. Locally-available infrastructure such as harvesting machinery and woodfuel depots for processing and storage is essential to provide woodfuel at an acceptable standard for the smaller-scale local heat market; that is, correctly sized woodchip with a lower moisture content (which infers a higher market value). With the right infrastructure it is possible to process SRP into high quality, boilerready wood chip to supply local markets. However, small producers currently lack these facilities as bespoke SRP machinery and infrastructure is expensive and it is difficult to justify private investment when markets are not yet fully developed.

\subsubsection{Lowering investment risk for SRP growers}

Despite having numerous environmental and socio-economic benefits, planting SRP is currently unappealing to the majority of farmers. It is traditionally viewed as a high risk, long-term commitment with high capital costs, poor cash flow and marginal returns. Under existing economic conditions, most farmers don't recoup the investment incurred during the establishment of the crop until seven years after planting and don't make any profit until they have sold their crop in year 10 . In the past many companies offering SRP purchase contracts have failed or pulled back from the venture before the crop is harvested leaving growers without markets.

Previous initiatives such as DEFRA's Energy Crops Scheme have provided 50\% establishment grants but no support thereafter [49]. There were no funds for market development and very little for infrastructure. As a result, many farmers are currently without contracts or markets for their crop and some are hundreds of miles from the nearest harvesting machine. Some growers have been forced into removing their crop at great expense. Hence, the current situation is one of too much risk and too little reward for growers. 
This must change if we are to encourage growers to plant significant areas of energy crops.

\subsubsection{Matching supply and demand to help achieve economies of scale}

At present, there are only a few small-scale growers of SRP located in the South West (SW) of England. These growers are relatively isolated and the infrastructure is not yet sufficient to support the development of the supply chain to a point where economies of scale can be achieved. This means that investment in SRP is not an economically attractive proposition for farmers, and results in a chicken and egg situation whereby there is insufficient supply to create a viable market for the product, and without a viable market there will be little incentive for farmers to upscale production.

Few secure long-term markets currently exist within SW England. Several multi-megawatt projects proposed for the SW failed due to lack of finance and failure to achieve planning permission [15]. This sends out the wrong message to farmers and discourages them from investing in SRP.

\section{Policy strategies and discussion}

In the previous section the priority issues for each of the six countries/regions were outlined. Due to space limitations, it is not possible to detail the policy strategies at country/region level to address these priority issues. In any case, they are summarised in Table 2. Instead, in this section a discussion and qualified interpretation of the policy strategies, highlighting the thorniest and most frequent issues, are provided.

In most of the EU countries, the cultivation of woody energy crops has proceeded at a low rate. Despite over 30 years of research and development and 25 years of policy support there are still only around 50,000 ha of SRP planted in the EU27 [31]. This slow development may be partially explained by time lags in adoption arising from a spatial diffusion process [50] and by lack of coherent policy support both at EU level and country/regions level [51]. Environmental standards and legislative provisions in the majority of countries are still lagging behind the rapid development of energy crops [20]. In particular the SRP bioenergy sector, as a small and incipient industry, tends to be the recipient of poorly constructed policy mechanisms [15].

The results obtained in this research indicate that long-term policy strategies, defined and implemented at national and regional level but coordinated at EU level, and backed up by the right economic incentives, must be undertaken if a wider development of the European SRP energy sector is the objective, which is in line with previous literature $[15,20,31,35,52,53]$. In this context, the recent result of the UK referendum on the EU membership may deeply affect the policy framework for this country and the Brexit implementation may question many of the policy insights obtained in this work for UK. In any case, at current usage levels, SRP biomass could be considered as an untapped resource, although there is a worldwide interest to extend its sustainable production significantly [54]. Increased planting of SRP would entail potential multifunctional benefits from an economic, environmental and social point of view, especially in marginal and less favoured areas taking apart areas of high nature-conservation value (see Introduction for references), which can justify the public support to this emerging sector. However, it has been detected that more integrated environmental and economic research is necessary to formulate standards that help support long-term economic and environmental sustainability of biomass production and avoid costly mistakes [20,55]. It has also been detected, in line with previous literature, that farmers and the SRP sector in general need trusted information to make decisions, which predominantly come down to financial considerations at an individual level [6,33]. Hence, the cost of plant propagules is one factor that constrains widespread planting; new techniques are required that simultaneously reduce unit costs of propagules and increase the speed of their availability $[16,20,56]$. Other important R\&D needs identified include yield improvement, in agreement with Searle and Malins [57], and SRP species adapted to the region specific conditions, e.g. species that use water more efficiently in southern Europe where bioenergy crop production is especially vulnerable to climate change [58]. Also, research is needed to develop internationally accepted criteria to ensure the sustainable production of biomass and international coordination between initiatives to improve coherence and efficiency in the development of sustainable biomass certification systems [59]. Our results highlight particular R\&D needs at country level: in UK, Irish and Spanish weaknesses in the lack of harvesting infrastructure and supply chain logistics were stated, whilst in Sweden, Poland and Germany a lack of profitable specialized machinery for SRP and lack of technological development to address this were identified. Also, improved clarity in policy would support the expansion of SRP. Hence, some ambiguity was noted in two areas of policy in particular: in Ireland related to the definition of biomass in applications for funding, and in Spain and Germany to land use categorisation.

The knowledge about SRP must not only be generated from $R \& D$ but also transferred to educate relevant groups about the benefits of SRP (including multifunctional benefits), particularly farmers, policy makers, public authorities and government agencies. First, this knowledge transfer should focus on a change in the mentality and attitudes of farmers with regards to the risk-taking associated to this innovative cultivation to help dispel the myths around it. For instance, previous studies cited a range of 'moral' (e.g. should not be using land for energy crops when there is a shortage of food), land quality, knowledge, profit and current farming practice comments as reasons for not growing SRP [60,61]. Farmers and the SRP sector in general need trusted information to make decisions, which predominantly come down to financial considerations at an individual level [61]. The role of public research organisations, universities and technological centres as catalysts for participation of the sector's agents in R\&D programs and training should be reinforced, with the particular aim of achieving public targets on the environment and on sustainable production. The need for research funding and closer working between $R \& D$ organisations, universities and industry is also vital. Enhanced information exchange through extension agents, providing market security and considering land reversion grants post-production are potential policy considerations [60]. Small-scale projects using established technologies are also required with energy crops introduced in a phased manner [15]. Second, knowledge transfer should serve to increase awareness of policy makers, public authorities and government agencies about the long-term positive impact of SRP in societal welfare as a whole and inform the development of public regulations for the sector, such as, justifying and defining specific funds and fully acknowledging SRP as a greening measure in the CAP. Our research points out that support for the sector must join up policy between different government departments, in agreement with previous studies [15]. In this respect, a lack of lobby groups supporting SRP was identified, which is a particular issue due to the way that the topic falls between 'two stools' in terms of government responsibility. The lack of any lobbying power has meant that the sector has been in the past the recipient of numerous policy measures that have failed [31].

In all the analysed countries/regions a greater financial support is highlighted as being necessary in order to grow the SRP market, and there was general agreement that some of this additional 
Table 2

Summary of policy strategies for the priority issues at country/region level.

\begin{tabular}{|c|c|c|c|c|c|c|c|c|c|c|}
\hline \multirow{2}{*}{$\begin{array}{l}\begin{array}{l}\text { Country } \\
\text { (region) }\end{array} \\
\text { Issue }\end{array}$} & \multicolumn{3}{|l|}{ Germany (Northern) } & \multicolumn{4}{|c|}{ Ireland (Midlands \& Western) } & \multicolumn{3}{|l|}{ Poland (Mazovia) } \\
\hline & $\begin{array}{l}\text { Highlight the } \\
\text { positive ecological } \\
\text { effects of SRP }\end{array}$ & $\begin{array}{l}\text { Inclusion of farmers } \\
\text { and local } \\
\text { authorities }\end{array}$ & $\begin{array}{l}\text { Enable regional } \\
\text { value creation and } \\
\text { create value-added } \\
\text { chains }\end{array}$ & $\begin{array}{l}\text { Development of a } \\
\text { policy development } \\
\text { group }\end{array}$ & $\begin{array}{l}\text { Education and } \\
\text { information for the } \\
\text { sector }\end{array}$ & $\begin{array}{l}\text { Re-classification of } \\
\text { energy crops and } \\
\text { address the } \\
\text { disparity with } \\
\text { forestry supports }\end{array}$ & $\begin{array}{l}\text { Development of a } \\
\text { Renewable Heat } \\
\text { Initiative to achieve } \\
\text { RES-H targets }\end{array}$ & $\begin{array}{l}\text { General lobbying } \\
\text { activities, especially } \\
\text { in the political and } \\
\text { business sectors }\end{array}$ & $\begin{array}{l}\text { Support for } \\
\text { biomass } \\
\text { providers and } \\
\text { development of } \\
\text { a proper } \\
\text { market }\end{array}$ & $\begin{array}{l}\text { Knowledge } \\
\text { dissemination } \\
\text { and technical } \\
\text { and } \\
\text { technological } \\
\text { development }\end{array}$ \\
\hline $\begin{array}{l}\text { Policy } \\
\quad \text { strategies }\end{array}$ & $\begin{array}{l}\text { - R\&D on positive } \\
\text { ecological effects } \\
\text { of SRP for } \\
\text { relatively bad } \\
\text { soils and areas } \\
\text { difficult to } \\
\text { cultivate (water } \\
\text { purification, } \\
\text { groundwater } \\
\text { stabilization and } \\
\text { ground erosion) } \\
\text { against the } \\
\text { background of } \\
\text { intensive land } \\
\text { use and climatic } \\
\text { change } \\
\text { - Increasing the } \\
\text { greening factor } \\
\text { of SRP in view of } \\
\text { their high } \\
\text { environmental } \\
\text { value and use as } \\
\text { an energy } \\
\text { resource } \\
\text { Cultivation of } \\
\text { SRP on fields on } \\
\text { which maize is } \\
\text { currently grown, } \\
\text { since its } \\
\text { energetic use is } \\
\text { higher and it is } \\
\text { ecologically } \\
\text { friendly }\end{array}$ & $\begin{array}{l}\text { - Creating separate } \\
\text { funding schemes } \\
\text { in order to make } \\
\text { clear the } \\
\text { difference } \\
\text { between } \\
\text { traditional field } \\
\text { crops and SRP } \\
\text { - Increasing the } \\
\text { greening factor } \\
\text { of SRP which } \\
\text { may serve as an } \\
\text { indirect } \\
\text { investment and } \\
\text { incentive for } \\
\text { farmers } \\
\text { - Improving } \\
\text { logistics and } \\
\text { information for } \\
\text { farmers from the } \\
\text { government } \\
\text { - Enforcing the } \\
\text { 'EEG-Umlage', } \\
\text { taking regional } \\
\text { advantages and } \\
\text { the good } \\
\text { ecobalance of } \\
\text { SRP into account }\end{array}$ & $\begin{array}{l}\text { - Supporting } \\
\text { networks of SRP } \\
\text { actors for } \\
\text { regional value } \\
\text { creation. They } \\
\text { have the } \\
\text { potential to } \\
\text { connect actors } \\
\text { from all regions } \\
\text { in Germany, } \\
\text { connect } \\
\text { producers, } \\
\text { suppliers and } \\
\text { consumers of SRP } \\
\text { wood, and foster } \\
\text { the improvement } \\
\text { of relevant } \\
\text { technologies }\end{array}$ & $\begin{array}{l}\text { - Creation of an } \\
\text { interdepartmental } \\
\text { body on energy } \\
\text { policy to counteract } \\
\text { other lobby groups } \\
\text { and fulfil the deficit } \\
\text { in policy } \\
\text { development for SRP } \\
\text { in Ireland }\end{array}$ & $\begin{array}{l}\text { Developing } \\
\text { information } \\
\text { factsheets, } \\
\text { workshops and } \\
\text { seminars to } \\
\text { tackle the } \\
\text { education deficit } \\
\text { and the myths } \\
\text { associated with } \\
\text { SRP, and to } \\
\text { develop a greater } \\
\text { understanding of } \\
\text { the sector and } \\
\text { advise those } \\
\text { involved in the } \\
\text { supply chain of } \\
\text { the overall } \\
\text { benefits of SRP } \\
\text { crops }\end{array}$ & $\begin{array}{l}\text { - Examining the } \\
\text { definition of } \\
\text { energy crops, and } \\
\text { look at other } \\
\text { crops to be } \\
\text { included in the } \\
\text { existing } \\
\text { bioenergy } \\
\text { scheme, not just } \\
\text { willow and } \\
\text { miscanthus } \\
\text { - Redefining the } \\
\text { grant supports } \\
\text { for forestry and } \\
\text { SRP to allow } \\
\text { energy crops to } \\
\text { compete } \\
\text { financially for } \\
\text { land use }\end{array}$ & $\begin{array}{l}\text { - Providing } \\
\text { support } \\
\text { mechanisms } \\
\text { such as a } \\
\text { Renewable Heat } \\
\text { Initiative to } \\
\text { enable closing } \\
\text { the gap between } \\
\text { the current } \\
\text { position and the } \\
12 \% \text { RES-H } \\
\text { targets for } 2016\end{array}$ & $\begin{array}{l}\text { - Lobbying to } \\
\text { create efficient } \\
\text { financial and } \\
\text { legislative } \\
\text { mechanisms and } \\
\text { schemes since in } \\
\text { the country } \\
\text { biomass overall } \\
\text { is marginalized } \\
\text { not only in } \\
\text { legislation but } \\
\text { also in business. } \\
\text { Currently, it is } \\
\text { much cheaper to } \\
\text { produce energy } \\
\text { from coal than } \\
\text { from biomass. In } \\
\text { terms of } \\
\text { renewable } \\
\text { energy sources, } \\
\text { only wind and } \\
\text { geothermal } \\
\text { energy are } \\
\text { considered } \\
\text { - Taking advantage } \\
\text { of the } \\
\text { Development } \\
\text { Strategy 2014 } \\
\text {-2020 where } \\
\text { specific } \\
\text { production } \\
\text { methods are not } \\
\text { stated and there } \\
\text { is an opportunity } \\
\text { to make biomass } \\
\text { a strong element } \\
\text { of energy } \\
\text { production }\end{array}$ & $\begin{array}{l}\text { - Creating a } \\
\text { sound } \\
\text { legislative } \\
\text { and financial } \\
\text { basis to allow } \\
\text { the } \\
\text { development } \\
\text { of a properly } \\
\text { developed } \\
\text { biomass } \\
\text { market and } \\
\text { encourage } \\
\text { further } \\
\text { players and } \\
\text { institutions } \\
\text { to become } \\
\text { part of the } \\
\text { new energy } \\
\text { production } \\
\text { process }\end{array}$ & $\begin{array}{l}\text { - Developing } \\
\text { promotional } \\
\text { and training } \\
\text { activities on } \\
\text { SRP, } \\
\text { especially } \\
\text { about } \\
\text { production } \\
\text { methods and } \\
\text { technologies, } \\
\text { special } \\
\text { machinery } \\
\text { and biomass } \\
\text { value chains }\end{array}$ \\
\hline
\end{tabular}




\begin{tabular}{|c|c|c|c|c|c|c|c|c|c|c|}
\hline Country & Spain (Andalusia & & & & Sweden (Skåne) & & UK (South West) & & & \\
\hline Issue & $\begin{array}{l}\text { Promote } \\
\text { resources to } \\
\text { share } \\
\text { information on } \\
\text { SRP among all } \\
\text { stakeholders }\end{array}$ & $\begin{array}{l}\text { Promotion of } \\
\text { biomass and focus } \\
\text { on its local } \\
\text { production }\end{array}$ & $\begin{array}{l}\text { Develop specific } \\
\text { legislation adapted } \\
\text { to SRP } \\
\text { characteristics }\end{array}$ & $\begin{array}{l}\text { Promote policies } \\
\text { and resources to } \\
\text { develop better R\&D }\end{array}$ & $\begin{array}{l}\text { Willow as part of } \\
\text { the greening in the } \\
\text { CAP }\end{array}$ & $\begin{array}{l}\text { Willow as a } \\
\text { multifunctional } \\
\text { crop }\end{array}$ & $\begin{array}{l}\text { Evidence base } \\
\text { review of SRP costs } \\
\text { and benefits }\end{array}$ & $\begin{array}{l}\text { Enabling SRP } \\
\text { infrastructure to } \\
\text { supply local heat } \\
\text { markets }\end{array}$ & $\begin{array}{l}\text { Lowering } \\
\text { investment risk for } \\
\text { SRP growers }\end{array}$ & $\begin{array}{l}\text { Matching supply } \\
\text { and demand to help } \\
\text { achieve economies } \\
\text { of scale }\end{array}$ \\
\hline $\begin{array}{l}\text { Policy } \\
\quad \text { strategies }\end{array}$ & $\begin{array}{l}\text { - Promoting } \\
\text { courses, } \\
\text { networking, } \\
\text { awareness } \\
\text { campaigns, } \\
\text { technical } \\
\text { visits, and } \\
\text { R\&D for all } \\
\text { players to } \\
\text { know more } \\
\text { about SRP, its } \\
\text { possibilities } \\
\text { and the way } \\
\text { it can be } \\
\text { developed } \\
\text { for utilization } \\
\text { in heating } \\
\text { systems and } \\
\text { later on as } \\
\text { possible } \\
\text { biofuels }\end{array}$ & $\begin{array}{l}\text { - Maintaining and } \\
\text { augmenting the } \\
\text { promotion of } \\
\text { biomass focusing } \\
\text { on its sustainable } \\
\text { production } \\
\text { which does not } \\
\text { compete with } \\
\text { food crops nor } \\
\text { endanger large } \\
\text { forests and on } \\
\text { producing as } \\
\text { locally as feasible } \\
\text { with the least } \\
\text { impacts possible } \\
\text { - Improvement of } \\
\text { two tools } \\
\text { already available: } \\
\text { Certified fuel } \\
\text { quality and } \\
\text { downscaling } \\
\text { systems }\end{array}$ & $\begin{array}{l}\text { - Providing clearer } \\
\text { information on } \\
\text { SRP schemes and } \\
\text { how to promote } \\
\text { SRP in CAP and } \\
\text { national/regional } \\
\text { legislation. E.g. } \\
\text { clearer criteria } \\
\text { regarding the } \\
\text { transformation of } \\
\text { agricultural land } \\
\text { into forest land }\end{array}$ & $\begin{array}{l}\text { R\&D in the field } \\
\text { of SRP. Issues: } \\
\text { machinery, } \\
\text { marginal lands, } \\
\text { conversion of } \\
\text { wooden biomass } \\
\text { to biofuels, } \\
\text { downscaling } \\
\text { systems, } \\
\text { fertilizers and } \\
\text { weed control, } \\
\text { and wastewater } \\
\text { use }\end{array}$ & $\begin{array}{l}\text { Fully } \\
\text { acknowledgment } \\
\text { of willow as } \\
\text { greening crop in } \\
\text { the framework of } \\
\text { the reform of the } \\
\text { CAP, removing } \\
\text { discrimination } \\
\text { against in } \\
\text { comparison to } \\
\text { other crops }\end{array}$ & $\begin{array}{l}\text { - Funding more } \\
\text { research on the } \\
\text { multifunctional } \\
\text { benefits of } \\
\text { willow which } \\
\text { should be } \\
\text { remunerated } \\
\text { such as } \\
\text { enhancing } \\
\text { biodiversity, } \\
\text { improving soil } \\
\text { and water } \\
\text { quality, flood } \\
\text { defence and } \\
\text { other effects }\end{array}$ & $\begin{array}{l}\text { - Supporting an } \\
\text { evidence base } \\
\text { review and cost/ } \\
\text { benefit analysis } \\
\text { of the } \\
\text { multifunctional } \\
\text { benefits of SRP. } \\
\text { This would seek } \\
\text { to achieve } \\
\text { recognition and } \\
\text { acceptance of } \\
\text { research outputs } \\
\text { that demonstrate } \\
\text { the } \\
\text { multifunctional } \\
\text { environmental } \\
\text { and socio- } \\
\text { economic } \\
\text { benefits provided } \\
\text { by SRP }\end{array}$ & $\begin{array}{l}\text { - Making available } \\
\text { dedicated } \\
\text { funding on a } \\
\text { regional basis for } \\
\text { harvesting } \\
\text { machinery, local } \\
\text { processing/ } \\
\text { storage depots } \\
\text { and associated } \\
\text { infrastructure. } \\
\text { Potential sources } \\
\text { of funding and } \\
\text { support include } \\
\text { grants from the } \\
\text { RDPE and the } \\
\text { ESIF } \\
\text { - Stimulating LAGs } \\
\text { to secure } \\
\text { funding via } \\
\text { LEADER-based } \\
\text { delivery of Rural } \\
\text { Development } \\
\text { Programme } \\
\text { grants, and LEPs } \\
\text { to channel RDPE } \\
\text { funding to this } \\
\text { effect. LEPs can } \\
\text { also to direct a } \\
\text { proportion of } \\
\text { their ESIF } \\
\text { funding into } \\
\text { LEADER projects } \\
\text { - Encouraging } \\
\text { producer groups } \\
\text { and co- } \\
\text { operatives, to } \\
\text { compliment } \\
\text { funding and help } \\
\text { to identify local } \\
\text { woodfuel heating } \\
\text { markets, } \\
\text { particularly in } \\
\text { off-gas areas } \\
\text { where the } \\
\text { multifunctional } \\
\text { benefits to the } \\
\text { local community } \\
\text { of growing } \\
\text { energy crops can } \\
\text { be maximised }\end{array}$ & $\begin{array}{l}\text { - Introducing } \\
\text { package of } \\
\text { measures } \\
\text { designed to } \\
\text { lower the } \\
\text { investment risk } \\
\text { to SRP growers } \\
\text { and strengthen } \\
\text { the business case. } \\
\text { This could } \\
\text { include crop } \\
\text { establishment } \\
\text { grants and some } \\
\text { level of } \\
\text { guarantee } \\
\text { - Offering interest- } \\
\text { free loans or } \\
\text { subsidy } \\
\text { payments for } \\
\text { planting SRP } \\
\text { where it can } \\
\text { make a } \\
\text { significant } \\
\text { difference to } \\
\text { flood defence/ } \\
\text { water quality. } \\
\text { Creation of a } \\
\text { carbon initiative } \\
\text { for carbon offset } \\
\text { - Rolling out a local } \\
\text { support scheme } \\
\text { by LEPs and local } \\
\text { authorities } \\
\text { making use of } \\
\text { local knowledge, } \\
\text { in the absence of } \\
\text { a nationally-run } \\
\text { scheme }\end{array}$ & $\begin{array}{l}\text { - Identifying and } \\
\text { supporting a } \\
\text { scheme } \\
\text { comprising one } \\
\text { or more pilot } \\
\text { projects which } \\
\text { links SRP } \\
\text { growers to end- } \\
\text { users to } \\
\text { demonstrate } \\
\text { economies of } \\
\text { scale, help match } \\
\text { SRP supply with } \\
\text { demand and to } \\
\text { kick-start local } \\
\text { production. This } \\
\text { could involve the } \\
\text { development of } \\
\text { one or more } \\
\text { larger scale or } \\
\text { several clusters } \\
\text { of smaller scale } \\
\text { biomass energy } \\
\text { installations } \\
\text { - Promoting the } \\
\text { role of LEPs and/ } \\
\text { or local } \\
\text { authorities to co- } \\
\text { ordinate this } \\
\text { initiative by } \\
\text { commissioning } \\
\text { feasibility studies } \\
\text { to identify } \\
\text { suitable locations } \\
\text { for pilot schemes, } \\
\text { and by } \\
\text { facilitating key } \\
\text { activities such as } \\
\text { the formation of } \\
\text { an SRP co- } \\
\text { operative or } \\
\text { producer group } \\
\text { and engaging } \\
\text { biomass energy } \\
\text { plant developers } \\
\text { and end-users of } \\
\text { heat }\end{array}$ \\
\hline
\end{tabular}


funding should come from regional and/or national governments. Farmers are unlikely to convert land until the present value of the investment returns exceeds the investment costs considerably [62]. Therefore, public incentives and a stable market are essential to compete with traditional crops and be commercially viable [52], since SRP plantations are in general less profitable when compared with agricultural crops [63-65]. Incentives may be provided on the supply side (e.g. establishment grants) and on the demand side (e.g. renewable obligation certificates (ROCs) and renewable heat incentives (RHIs) [66]. In biofuels in general it has been indicated that policy must emphasize the changes needed and tie incentives to improved greenhouse gas reduction and environmental performance [67]. Therefore, linking multifunctional benefits of SRP and targeted payments could be an option to explore further. The introduction of targeted subsidies as an incentive for growers may help to develop local supply chains and improve management of cash flows during establishment $[15,20,66]$. Previous studies also indicate that policies which encourage farmers to de-invest in own farm machinery, or incentivise the purchase of specific energy crop machinery, may play an important role [68]. Also, it has been pointed out that the strategy of on-farm diversification toward woody crops under long-term contractual arrangements between farmers and energy plant operators could be relevant for farmers to mitigate the risks associated to cash crop prices fluctuations $[53,61,69]$. Another solution to reduce the farmers' exposure to the economic risks associated with the long-term land commitment required for perennial crops could be indexing the biomass prices annually to cereal market prices, which could be included in longterm contracts for biomass trading between farmers and energy producers [35]. On the other hand, demand side incentives need to overcome the higher capital cost associated with biomass conversion equipment compared with equipment used for fossil fuels; but, in particular, they must overcome any difference in price between fossil fuels and energy crops [66]. According to the Swedish experience, the development of an infrastructure and a market for willow chips are essential pre-conditions for the development of SRP for bioenergy, being probably the most important factor in the location of willow plantations the existence of consumers that can guarantee a long-term demand [25,70].

\section{Conclusions}

Biomass is increasingly being seen as an important energy source for Europe. SRP offer multifunctionality in addition to their high woody biomass productivity. Additionally, biomass generation from woody energy crops reduces dependency on fossil fuels and improves energy security, and may represent a new market niche and generate green employments especially in low-productive capacity agricultural areas or deforested and unproductive forest areas. These promising attributes are not being fully exploited, however, as there are a variety of obstacles and barriers hindering or even preventing the further development of the SRP bioenergy sector. These obstacles and barriers comprise, amongst others, missing or unfavourable legal framework conditions, missing financial support as well as various technical and non-technical barriers.

The issues that must be tackled in order to ensure the creation of a successful path to market for SRP are numerous and complex, but not insurmountable. Some issues are unique to one country/region due to variations in market advancement, existing national/local policies and the local characteristics of the area. However, there are also common obstacles at EU level and policy strategies to the wider uptake of SRP across each of the different European countries. In general, there is a lack of awareness of the multifaceted benefits of SRP at the level of both farmers and policy makers and thus a co-ordinated top-down and bottom-up approach is needed in order to promote the widespread uptake of SRP. There is also a lack of knowledge of SRP as both a feasible crop choice for farmers and as an energy source for heat producers. This is due both to a lack of dissemination of knowledge and the absence of recognition of SRP in public policies. SRP is unlikely to be looked on favourably by farmers and producers unless it is afforded the same benefits, subsidies and support that other crops and fuel sources receive from governments. Change in policy is crucial and the support of bureaucrats at the local, regional and national level is vital for this to be effected. R\&D must also play a part in ensuring there is clear and concrete evidence in the field of the environmental and socioeconomic benefits of SRP. The simultaneous dissemination of this knowledge upwards to policy makers and downwards to producers and farmers is critical in the success of SRP. The formation and development of groups to lobby for the uptake and support of SRP and bioenergy is also likely to be of great importance. Finally, it is necessary to highlight that the effective implementation of the UK Brexit may deeply affect the policy framework for the development of SRP in this country and further research should be undertaken.

\section{Acknowledgments}

We would like to express our appreciation for the financial support received from the FP7 EU Project "European Regions fostering Innovation for Sustainable Production and Efficient Use of Woody Biomass (Rokwood)", European Union FP7-Regions-20122013-1 (Transnational Cooperation between Regional ResearchDriven Clusters), Grant Agreement No. 319956.

\section{References}

[1] EC, The EU Explained - Energy: Sustainable, Secure and Affordable Energy for Europeans, European Commission. Directorate-general for Communication Citizens Information, Brussels, Belgium, 2014. https://ec.europa.eu/energy/ sites/ener/files/documents/energy.pdf.

[2] EC, Directive 2009/28/EC of the European Parliament and of the Council of 23 April 2009 on the Promotion of the Use of Energy from Renewable Sources and Amending and Subsequently Repealing Directives 2001/77/EC and 2003/ 30/EC (Text with EEA Relevance), European Commission (EC), 2009. http:// eur-lex.europa.eu/legal-content/EN/ALL/?uri=CELEX:32009L0028.

[3] EC, Energy for the future: renewable sources of energy, White paper for a community strategy and action plan, Eur. Comm. Com. 97 (599) (1997). Brussels.

[4] N. Scarlat, J.-F. Dallemand, F. Monforti-Ferrario, V. Nita, The role of biomass and bioenergy in a future bioeconomy: policies and facts, Environ. Dev. 15 (2015) 3-34.

[5] H. McKay, Environmental, economic, social and political drivers for increasing use of woodfuel as a renewable resource in Britain, Biomass Bioenergy 30 (4) (2006) 308-315.

[6] C. Parra-López, S. Sayadi, V.H. Durán Zuazo, Production and use of biomass from short-rotation plantations in Andalusia, southern Spain: limitations and opportunities, New Medit. 14 (3) (2015) 40-49.

[7] S.N. Djomo, O. El Kasmioui, R. Ceulemans, Energy and greenhouse gas balance of bioenergy production from poplar and willow: a review, Global Change Biol. Bioenergy 3 (3) (2011) 181-197.

[8] H. Langeveld, F. Quist-Wessel, I. Dimitriou, P. Aronsson, C. Baum, U. Schulz, A. Bolte, S. Baum, J. Koehn, M. Weih, H. Gruss, P. Leinweber, N. Lamersdorf, P. Schmidt-Walter, G. Berndes, Assessing environmental impacts of short rotation coppice (SRC) expansion: model definition and preliminary results, Bioenergy Res. 5 (3) (2012) 621-635.

[9] F. Sartori, R. Lal, M.H. Ebinger, D.J. Parrish, Potential soil carbon sequestration and $\mathrm{CO} 2$ offset by dedicated energy crops in the USA, Crit. Rev. Plant Sci. 25 (5) (2006) 441-472.

[10] P. Thornley, P. Gilbert, S. Shackley, J. Hammond, Maximizing the greenhouse gas reductions from biomass: the role of life cycle assessment, Biomass Bioenergy 81 (2015) 35-43.

[11] F. Hedenus, C. Azar, Bioenergy plantations or long-term carbon sinks? - A model based analysis, Biomass Bioenerg. 33 (12) (2009) 1693-1702.

[12] M. Henseler, N. Röder, H. Liebersbach, P. Kreins, B. Osterburg, The mitigation potential and cost efficiency of abatement-based payments for the production of short-rotation coppices in Germany, Biomass Bioenergy 81 (2015) 592-601.

[13] N. Röder, M. Henseler, H. Liebersbach, P. Kreins, B. Osterburg, Evaluation of land use based greenhouse gas abatement measures in Germany, Ecol. Econ. 
117 (2015) 193-202.

[14] M. Manzone, S. Bergante, G. Facciotto, Energy and economic evaluation of a poplar plantation for woodchips production in Italy, Biomass Bioenergy 60 (2014) 164-170.

[15] P.W.R. Adams, K. Lindegaard, A critical appraisal of the effectiveness of UK perennial energy crops policy since 1990, Renew. Sustain. Energy Rev. 55 (2016) 188-202.

[16] G.A. Keoleian, T.A. Volk, Renewable energy from willow biomass crops: life cycle energy, environmental and economic performance, Crit. Rev. Plant Sci. 24 (5-6) (2005) 385-406.

[17] E. Schreurs, T. Voets, T. Thewys, GIS-based assessment of the biomass potential from phytoremediation of contaminated agricultural land in the Campine region in Belgium, Biomass Bioenergy 35 (10) (2011) 4469-4480.

[18] K. Verheyen, M. Buggenhout, P. Vangansbeke, A. De Dobbelaere, P. Verdonckt, D. Bonte, Potential of Short Rotation Coppice plantations to reinforce functional biodiversity in agricultural landscapes, Biomass Bioenergy 67 (2014) 435-442.

[19] N. Witters, S. Van Slycken, A. Ruttens, K. Adriaensen, E. Meers, L. Meiresonne, F.M.G. Tack, T. Thewys, E. Laes, J. Vangronsveld, Short-rotation coppice of willow for phytoremediation of a metal-contaminated agricultural area: a sustainability assessment, Bioenergy Res. 2 (3) (2009) 144-152.

[20] J. Dauber, M.B. Jones, J.C. Stout, The impact of biomass crop cultivation on temperate biodiversity, Glob. Change Biol. Bioenergy 2 (6) (2010) 289-309.

[21] M. Favero, D. Pettenella, Italian import flows of woody biomasses for energy use: a sustainable supply? New Medit. 13 (2) (2014) 56-64.

[22] S. Hauk, S. Wittkopf, T. Knoke, Analysis of commercial short rotation coppices in Bavaria, southern Germany, Biomass Bioenergy 67 (2014) 401-412.

[23] T. Voets, T. Kuppens, T. Cornelissen, T. Thewys, Economics of electricity and heat production by gasification or flash pyrolysis of short rotation coppice in Flanders (Belgium), Biomass Bioenergy 35 (5) (2011) 1912-1924.

[24] W. Zegada-Lizarazu, H.W. Elbersen, S.L. Cosentino, A. Zatta, E. Alexopoulou, A. Monti, Agronomic aspects of future energy crops in Europe, Biofuels Bioprod. Biorefining-Biofpr 4 (6) (2010) 674-691.

[25] B. Mola-Yudego, J.R. Gonzalez-Olabarria, Mapping the expansion and distribution of willow plantations for bioenergy in Sweden: lessons to be learned about the spread of energy crops, Biomass Bioenerg. 34 (4) (2010) 442-448.

[26] R. Venendaal, U. Jørgensen, C.A. Foster, European energy crops: a synthesis, Biomass Bioenergy 13 (3) (1997) 147-185.

[27] B. Mola-Yudego, P. Pelkonen, The effects of policy incentives in the adoption of willow short rotation coppice for bioenergy in Sweden, Energy Pol. 36 (8) (2008) 3062-3068.

[28] A. Roos, H. Rosenqvist, E. Ling, B. Hektor, Farm-related factors influencing the adoption of short-rotation willow coppice production among Swedish farmers, Acta Agric. Scand. Sect. B-Soil Plant Sci. 50 (1) (2000) 28-34.

[29] H. Rosenqvist, A. Roos, E. Ling, B. Hektor, Willow growers in Sweden, Biomass Bioenergy 18 (2) (2000) 137-145.

[30] I. Dimitriou, H. Rosenqvist, G. Berndes, Slow expansion and low yields of willow short rotation coppice in Sweden; implications for future strategies, Biomass Bioenergy 35 (11) (2011) 4613-4618.

[31] K. Lindegaard, M. Holley, A. Lamley, P. Zapata-Aranda, S. Sayadi, C. ParraLópez, V.H. Durán-Zuazo, G. Esteban-López, T. Janik, J. Gopek, M. Kiner, P. Daly, E. von Engelbrechten, A. Henriksson, S. Paulrud, C. Knauer, Rokwood: fuelling dialogue between biomass research, industry, policy and business, Aspects Appl. Biol. 131 (2015) 33-42.

[32] V.H. Durán Zuazo, J.A. Jiménez Bocanegra, F. Perea Torres, C.R. Rodríguez Pleguezuelo, J.R. Francia Martínez, Biomass yield potential of paulownia trees in a semi-arid Mediterranean environment (S Spain), Int. J. Renew. Energy Res. (IJRER) 3 (4) (2013) 789-793.

[33] S. Sayadi, C. Parra-López, V.H. Durán-Zuazo, V. Magnolfi, Shsort-rotation wooden biomass production: barriers and opportunities in Andalusia (southern Spain), in: 22nd European Biomass Conference and Exhibition. Hamburg, Germany, 23-26 June, Proceedings Book Edited with ISBN 978-8889407-52-3, ISSN 2282-5819, 2014.

[34] G. San Miguel, B. Corona, D. Ruiz, D. Landholm, R. Laina, E. Tolosana, H. Sixto, I. Cañellas, Environmental, energy and economic analysis of a biomass supply chain based on a poplar short rotation coppice in Spain, J. Clean. Prod. 94 (2015) 93-101.

[35] E. Krasuska, H. Rosenqvist, Economics of energy crops in Poland today and in the future, Biomass Bioenergy 38 (2012) 23-33.

[36] EC, Energy 2020 a Strategy for Competitive, Sustainable and Secure Energy. Communication from the Commission to the European Parliament, the Council, the European Economic and Social Committee and the Committee of the Regions (COM/2010/0639 Final), European Commission (EC), 2010. http:// eur-lex.europa.eu/legal-content/EN/TXT/?uri=celex:52010DC0639.

[37] K.N. Lindegaard, P.W.R. Adams, M. Holley, A. Lamley, A. Henriksson, S. Larsson, H.-G. von Engelbrechten, G. Esteban Lopez, M. Pisarek, Short rotation plantations policy history in Europe: lessons from the past and recommendations for the future, Food Energy Secur. 5 (3) (2016) 125-152.

[38] A. Kolios, G. Read, A Political, Economic, social, technology, legal and environmental (PESTLE) approach for risk identification of the tidal industry in the United Kingdom, Energies 6 (10) (2013) 5023-5045.

[39] Z. Srdjevic, R. Bajcetic, B. Srdjevic, Identifying the criteria set for multicriteria decision making based on SWOT/PESTLE analysis: a case study of reconstructing a water intake structure, Water Resour. Manag. 26 (12) (2012)
3379-3393.

[40] R.O.K.W.O.O.D. Rokwood, European Regions Fostering Innovation for Sustainable Production and Efficient Use of Woody Biomass (ROKWOOD), 2016. FP7 EU Project, European Union FP7-Regions-2012-2013-1, www.rokwood. eu.

[41] European_Union, Regulation (EU) No 1307/2013 of the European Parliament and of the Council of 17 December 2013 Establishing Rules for Direct Payments to Farmers under Support Schemes within the Framework of the Common Agricultural Policy and Repealing Council Regulation (EC) No 637 2008 and Council Regulation (EC) No 73/2009, 2013. http://eur-lex.europa.eu/ legal-content/EN/TXT/?qid=1436267634754\&uri=CELEX:32013R1307.

[42] IrBEA, Energy Crops Group. Irish Bioenergy Association (IrBEA), 2016. http:// www.irbea.org/energy-crops.

[43] DAFM, Bioenergy Scheme. Department of Agriculture, Food and the Marine DAFM, 2016. https://www.agriculture.gov.ie/bioenergyscheme.

[44] IWEA, IWEA Position on the Valuation (Amendment) (No. 2) Bill 2012 "The Bill”, 2015. http://mnag.ie/wp-content/uploads/2015/02/Letter_to_Minister_ Harris_18022015_Template.docx.

[45] Jefatura_del_Estado, Real Decreto-Ley 1/2012 por el que se procede a la suspensión de los procedimientos de preasignación de retribución en las nuevas instalaciones de producción de energía eléctrica en régimen especial. BOE 2801-12, 2011.

[46] CNMC, Informe marco sobre la demanda de energía eléctrica y gas natural, y su cobertura. Horizonte 2013-2017, Comisión Nacional de los Mercados y la Competencia - CNMC, 2014. https://www.cnmc.es/Portals/0/Ficheros/Energia/ Informes/20140308_Informe_Marco_2013.pdf.

[47] EC, Greening. European Comission, 2016. http://ec.europa.eu/agriculture/ direct-support/greening/index_en.htm.

[48] F. Tropea, CAP Simplification: State of Play. European Parliamentary Research Service Blog, 2016. https://epthinktank.eu/2016/01/08/cap-simplificationstate-of-play/.

[49] K. Lindegaard, Why We Need Any Energy Crops Scheme 3, Crops4Energy Bristol, 2013. http://www.crops4energy.co.uk/wp-content/uploads/2013/08 Critical-appraisal-of-the-ECS-final-version.pdf.

[50] P. Alexander, D. Moran, M.D.A. Rounsevell, P. Smith, Modelling the perennial energy crop market: the role of spatial diffusion, J. R. Soc. Interface 10 (88) (2013).

[51] P. Sinclair, B. Cohen, Y. Hansen, L. Basson, R. Clift, Stakeholder engagement within the sustainability assessment of bioenergy: case studies in heat, power and perennial and annual crops from the UK, Biomass Bioenergy 73 (2015) $11-22$.

[52] V.H. Durán Zuazo, C.R. Rodríguez Pleguezuelo, J.R. Francia, S. Sayadi J.A. Jiménez, F. Perea, Biomass of short-rotation woody crops for sustainable energy production: opportunities and challenges, Span. J. Rural Dev. (SJRD) 5 (1) (2014) 21-46

[53] A. Ridier, Farm level supply of short rotation woody crops: economic assessment in the long-term for household farming systems, Can. J. Agric. Econ.-Rev. Can. Agroecon. 60 (3) (2012) 357-375.

[54] L. Raslavicius, B. Azzopardi, A.K. Kopeyka, J. Saparauskas, Steep increases in biomass demand: the possibilities of short rotation coppice (SRC) agroforestry, Technol. Econ. Dev. Econ. 21 (3) (2015) 495-518.

[55] J. Kohn, Socio-economics in SRC - a review on concepts and the need for transdisciplinary research, Landbauforsch. Volkenrode 59 (3) (2009) $223-232$.

[56] C.J. Atkinson, Establishing perennial grass energy crops in the UK: a review of current propagation options for Miscanthus, Biomass Bioenergy 33 (5) (2009) 752-759.

[57] S.Y. Searle, C.J. Malins, Will energy crop yields meet expectations? Biomass Bioenergy 65 (2014) 3-12.

[58] G. Tuck, M.J. Glendining, P. Smith, J.I. House, M. Wattenbach, The potential distribution of bioenergy crops in Europe under present and future climate, Biomass Bioenergy 30 (3) (2006) 183-197.

[59] J. van Dam, M. Junginger, A. Faaij, I. Jürgens, G. Best, U. Fritsche, Overview of recent developments in sustainable biomass certification, Biomass Bioenergy 32 (8) (2008) 749-780.

[60] N.J. Glithero, P. Wilson, S.J. Ramsden, Prospects for arable farm uptake of Short Rotation Coppice willow and miscanthus in England, Appl. Energy 107 (2013) 209-218.

[61] C. Sherrington, J. Bartley, D. Moran, Farm-level constraints on the domestic supply of perennial energy crops in the UK, Energy Policy 36 (7) (2008) 2504-2512.

[62] O. Musshoff, Growing short rotation coppice on agricultural land in Germany: a Real Options Approach, Biomass Bioenergy 41 (2012) 73-85.

[63] R.J. Faasch, G. Patenaude, The economics of short rotation coppice in Germany, Biomass Bioenergy 45 (2012) 27-40.

[64] J. Schweier, G. Becker, Economics of poplar short rotation coppice plantations on marginal land in Germany, Biomass Bioenergy 59 (2013) 494-502.

[65] F. Sgroi, A.M. Di Trapani, M. Fodera, R. Testa, S. Tudisca, Economic assessment of Eucalyptus (spp.) for biomass production as alternative crop in Southern Italy, Renew. Sust. Energ. Rev. 44 (2015) 614-619.

[66] A.W. Bauen, A.J. Dunnett, G.M. Richter, A.G. Dailey, M. Aylott, E. Casella, G. Taylor, Modelling supply and demand of bioenergy from short rotation coppice and Miscanthus in the UK, Bioresour. Technol. 101 (21) (2010) $8132-8143$ 
[67] A. Karp, G.M. Richter, Meeting the challenge of food and energy security, J. Exp. Bot. 62 (10) (2011) 3263-3271.

[68] N.J. Glithero, P. Wilson, S.J. Ramsden, Optimal combinable and dedicated energy crop scenarios for marginal land, Appl. Energy 147 (2015) 82-91.

[69] H. Rosenquist, G. Berndes, P. Borjesson, The prospects of cost reductions in willow production in Sweden, Biomass Bioenerg. 48 (2013) 139-147.

[70] A. Thomas, A. Bond, K. Hiscock, A GIS based assessment of bioenergy potentia in England within existing energy systems, Biomass Bioenerg. 55 (2013) $107-121$. 